\title{
Citizenship Education from a Swedish Perspective
}

\author{
Dr Lisbeth Lindström \\ Luleå University of technology \\ Department of Education \\ Universitetsområdet Porsön, 97187 Luleå, Sweden \\ Tel: 46-92-049-3148Ｅ-mail: Lisbeth.Lindstrom@ltu.se
}

Received: Feb. 25, 2013 Accepted: April 2, 2013 Published: May 1, 2013

doi:10.5296/jse.v3i2.3321～URL: http://dx.doi.org/10.5296/jse.v3i2.3321

\begin{abstract}
The purpose of this article is to highlight some of the international research conducted in the field of citizenship education, and discuss the contents of people's citizenship that are visible in the steering instruments of the Swedish compulsory- and upper secondary schools such as the school law, curriculum and syllabi. Of interest has been the study on how these control instruments describe and illustrate the concept of citizenship and the related concepts. The study highlights the content that is expected to be taught compared with the actual experiences from citizenship education research.

In this research, textual analysis is used as a method to review the structure of the text and to scrutinize the content.

From the analysis of the national steering documents, it is possible to argue that young people in Sweden have the opportunity to both learn about democracy and be active citizens. It can also be argued that students have the opportunity to be a part of the democratic working framework in practice, which can prepare them for active participation in society later in life. However, this research does not give any answer to whether what is political rhetoric in documents is also the educational outcome of the pedagogical practice.
\end{abstract}

Keywords: Citizenship Education, Citizenship, National Policy, Education, Curriculum 


\section{Introduction}

A citizen may be described as a member of a political community or state, who has certain legal, social and moral rights, duties and responsibilities. Citizenship is a political concept with a variety of rights and responsibilities in a given political community. These rights and responsibilities change over time as the result of social struggle, economic change and shifts in governing ideology. The idea of citizenship is built on the principle of equal value and equal opportunity for the people to take part in and influence public activities. Even though citizenship can mean different things in different nations, it also has a broader sociological and historical meaning that is universal (Petersson, Hermansson, Micheletti, Teorell \&Westholm, 1998). It may also appear as an identity that is viewed as dynamic and elusive, and an object of continuous negotiation in a global world (Sandström Kjellin \& Stier, 2008). For example, Vinken (2005) focuses on citizenship defined as the process in which young people develop trust in others and in society's institutions and associations, which, to some degree, serve a public cause. Sandström Kjellin and Stier (2008) even argue that we live in a world that is more globalised than in any other historical era.

Inglehart (1997) and Giddens (1991) state that young citizens participate in society with "self-actualizing” or "self-reflexive” involvements in personally meaningful causes guided by their own lifestyles and shifting social networks. In the light of new knowledge and experiences, people constantly reconsider and redevelop their self (Giddens, 1991). A portfolio with skills for citizenship has been identified as to be able to show mutual respect to others, to have social awareness, to be able to take self-responsibility, and to have good self-confidence and self-worth (Hall, Williams \& Coffey, 2010). Schreiner and Sjöberg (2007) argue that when young people choose an education, they simultaneously express important components of their identity. Education is seen as a means for self-actualization, for fulfilling and developing personal talents and abilities. Moreover, late-modern societies (Western modernised countries) attempt to develop citizens who are self-directed and self-expressive individuals. Consequently, Schreiner and Sjöberg (2007) claim that students in late-modern classrooms might reasonably expect their values and voices to be taken into account in one way or another.

Citizenship is not a school subject at Swedish schools. Aspects and perspectives of people's citizenship are included as a part of different school subjects such as civics and history. Citizenship is a part of the Swedish school system expressed as "the Swedish school system's value ground/fundamental values" that is supposed to permeate all activities in the elementary and secondary schools.

The purpose of this paper is to highlight some of the international research in the field of citizenship education, and to make visible and discuss the contents, that have connection to people's citizenship, of the steering instruments of the compulsory upper secondary school Swedish education such as school law, curriculum and syllabi. The main interest is to study how these control instruments describe and illustrate the concept of citizenship and related concepts, along with the expected subject content, and to compare this with experiences from citizenship education research. The research question is how steering instruments and control 
instruments relate to the concept of citizenship in the Education Act (2010:800), the Curriculum for compulsory schools, preschools and leisure-time centres (LGR11), the Curriculum for secondary schools (LGY11 and syllabuses for civic studies at Compulsoryand Upper secondary school.

The paper is disposed as follows: general information about the Swedish system are presented under the heading "The Swedish school system”, theories about citizenship are presented under the heading 'Young people and their Citizenship' along with the experiences in research of citizenship education. The method used in the research are presented under the heading 'Method'.

The results of the study are presented under two headings: Steering documents in the Swedish school system and Syllabuses for civic studies at compulsory and upper secondary schools. And in the final chapter, Discussions and Conclusions, the findings are discussed and some conclusions are drawn.

\section{The Swedish school system}

The school system in Sweden embraces Preschool class, Compulsory school, Upper Secondary school and Adult Education.

In Sweden, schooling is compulsory for all children aged 7-16. Preschool is an educational group activity for children from the age of one until they start school. Under the Education Act (2010:800), municipalities are required to provide preschool activities and childcare for children aged 1-12 years.

In Sweden, the leisure-time centre is a pedagogical group activity for Swedish school children up to twelve years. Children attending the leisure-time centre are enrolled at the centre. Activities at the leisure-time centre can be run as a free standing group activity, but usually in varying degrees, integrated with preschool class and compulsory education. Approximately $80 \%$ of all children in Sweden aged between six and nine years, and about $10 \%$ of those between ten and twelve years are enrolled at the leisure-time centres (Skolverket, 2011; Swedish National Agency for Education, 2011).

Compulsory school involves nine school years and is mandatory and free of charge. The vast majority of schools in Sweden are municipally-run, which means that the municipality is the authority responsible for the school. A vast majority of compulsory school pupils, $88 \%$, attend municipal schools. Independent compulsory schools are open to all children and must be approved by the National Agency for Education. About $12 \%$ of the total school population attend independent compulsory schools. Education in compulsory schools, both municipalityrun and independent, is subject to the Swedish curriculum for compulsory schools, preschools and leisure-time centres (2011) decided by the Swedish government. Compulsory school education is arranged by municipal schools, state run Sami schools, independent compulsory schools, international schools and national boarding schools.

Upper secondary school is free and non-compulsory, available for those aged 16-20 years. Each municipality is legally required to provide upper secondary education to all pupils who 
have completed compulsory school. The proportion of pupils who achieved eligibility to upper secondary school was $93.7 \%$ from independent compulsory schools and $88.2 \%$ from schools run by municipalities. Upper secondary school offers various kinds of programmes. There are 18 national programmes at Upper secondary school, 12 vocational programmes and six college preparatory programmes that last for three years. Over $48 \%$ of upper secondary schools are independent schools.

\section{Young people and their Citizenship}

Many researchers are engaged in questions about youth and citizenship, most of them in the context of youth, education and citizenship. Lawy and Biesta (2006) claim that in recent years, young people have been targeted by a range of government policies and initiatives aimed at countering the argument that they have become alienated from the political and democratic process.

Osler and Starkey (2006) examine the role of education for democracy (EDC) and citizenship in responding to political challenges, setting national policy developments in both Europe and international contexts and exploring the growing international consensus on human rights as the underpinning principles of EDC. Osler and Starkey (2006) argue that there is a recognition that democracy is essentially fragile and depends on the active engagement of the citizens, not just in voting, but in developing and participating in sustainable and cohesive communities. In numerous studies from different parts of the world, it is evident that a major objective of education for national citizenship is to ensure that young people understand their roles within the constitutional and legal framework of the state in which they live (ibid.).

Beauregard and Bounds (2000) state the nation state is no longer as dominant as it once was and this is dependent on two forces, globalization and cultural diversity. As a response to this, they suggest an alternate concept of "cosmopolitan citizenship" in recognition of the multiplicity of the world. Their argument for using cosmopolitan citizenship is their concern for vulnerable groups and oppressed communities. A cosmopolitan approach places obligations on citizens that are above the obligations to their own nation. Cosmopolitan citizenship is the idea of a varied and multi-cultural identity in relation to other signifiers such as ethnicity, class etc (ibid). Sandström Kjellin and Stier (2008) argue about the needfulness of teachers' work in classrooms to stimulate people's active participation and to promote empathy for others as the prime characteristics of a cosmopolitan identity. Moreover, claiming that pupils at school are exposed to contradictory identify-construction processes, the partial dissolution of national identities and the construction of a cosmopolitan equivalent on the one hand and on the other hand, the forces that frame traditional and national identities.

Biesta, Lawy and Kelly (2009) and Biesta and Lawy (2006) argue that young people's citizenship learning is not just a cognitive function; rather, it is a process that is situated, related and uniquely linked to young people's individual life-trajectories. Furthermore, citizenship education should focus on young people in context and on the social-, economic-, cultural and political context in which they live their lives. Moreover, using the concept “citizenship as practice”, Lawy and Biesta (2006) claim that everyone in the society, 
including young people, are citizens who simply move through, “citizenship-as-practice”, from the cradle to the grave. Instead of seeing citizenship as the outcome of a learning trajectory, they suggest that young people must learn to be citizens as a consequence of their participation in the actual practices that make up their lives. Biesta, Lawy and Kelly (2009) claim that factors that provide young people with opportunities and experiences are crucial to the process of citizenship learning. These factors include the young to have a say, to be taken seriously and to have influence. To teach attitudes and values, teachers must first scrutinise their own attitudes and values with a view to analysing how, why, and when learning takes place.

Süllke (2007) argues that the education of citizenship needs to start with the strengthening of self-perception, the development of personality and self-confidence, communication and emotional skills. The development of critical thought is said to centre on acquiring self-confidence. If pupils are not encouraged to build up their self-confidence, they are not ready to learn. Schreiner and Sjöberg (2007) state teaching must build on an understanding of students' values, cultures, priorities and concerns.

Considering the future societies, Arnot (2006) questions what sort of citizens will be needed in the future and how youths should best be prepared for the social changes that will occur. Beck and Beck-Gernsheim (2002) describe what they call “Freedom's Children”, meaning children who have been brought up, unlike their parents, to become choosers, or consumers of what life has to offer. This new culture is described as a self-culture were young people might feel that they are free to choose their social group, education, life-style and values. Today, young people can select from a wider assortment of identity choices and can take a more active role in their future planning. This may induce confusion among individuals who may find the many possibilities intimidating (Côté,1996; Schwartz, Côté \& Arnett, 2005).

Like Biesta and Lawy (2006), Smith, Lister, Middleton and Cox (2005) argue that rather than seeing young citizenship as something starting with adulthood, "the fluidity of the young people's citizenship self-identity suggests that transitions to citizenship are negotiated throughout the life-course” (p. 426). Their conclusion calls for a more conceptually comprehensive view of citizenship that young people's status as "real citizens" can be better understood. A way of doing that is through a greater recognition of and support for what young people already do as citizens.

There are both privileges and obligations attached to people's citizenship. Ross (2007) problematizes the relationship between identity and citizenship with a special interest in citizenship and rights. She argues that education for active citizenship must address and encompass both the nature of multiple identities and the extension of civic rights to minorities. A motive is that certain rights have been placed above the nation-state, for example, the Universal Declaration of Human Rights that places a moral obligation on the signatory state to respect greater rights. A focus on the possible enhancement of rights will provide a powerful vehicle for learning through deliberative democracy (Ross, 2007). Ross (2007) argues that active citizenship requires more than voluntary activities; it is about the ability to engage in action for social change. She concludes that young people need a ground to explore 
what citizenship means in an active and participatory manner in contrast to civic education that has a strong tradition of transmitting symbolic and ironic aspects of citizenship.

Bennett, Wells and Rank (2009) ask how civic education can keep pace with changing political identifications and practices of new generations of citizens such as changing citizen identity styles and learning opportunities in various online and offline environments. The results of their research on school-based civic education in different post-industrial democracies showed that the preponderance of school-based civic education programmes reflected not only on traditional paradigms of dutiful citizenship (DC) oriented to government through parties and voting, but also on civic learning opportunities that reflected more self-actualizing (AC) styles. Bennett et. al (2009) claim that the various approaches to teaching in schools and colleges are often significantly out of step with the young people's preferred learning styles - resulting in negative outcomes for civic learning. Bennett, Wells and Rank (2009) state that the result is an expanded set of learning categories that recognize the value of different citizenship styles and emerging online environments that may supplement or supplant school civics (Bennett, 2003).

\section{Citizenship education}

Across the world, many governments have chosen to develop programmes for citizenship education and learning focused on the school sector by the belief that it is the young people who are perhaps most in need of citizenship education. Citizenship education is an ideological and normative project aimed at providing young people and their teachers with the necessary competence to navigate in a multi-cultural and globalized world. Kisby and Sloam (2012) argue that citizenship has become a major topic for debate and a subject of public policy in recent years as policy-makers and others across the Western world have tried to respond to what is seen as a weakening of democracy. An underlying idea is to enable all people's democratic participation in the classroom dialogues. When it comes to Citizenship Education, Print (2007) states that of all the options available for young people to learn about participation in democracy, the most strongly favoured and advocated is the school. However, everyone does not agree; it is also argued that the study of citizenship education in schools is the wrong place to start (Garratt \& Piper, 2010).

Fiehn (2007) argues that citizenship education is an important part of the development of young people. By enabling them to learn about their rights and responsibilities, to understand how society works, citizenship prepares them for dealing with the challenges they face in life and to learn and practice new skills. Through citizenship education, young people are encouraged and given opportunities to take action on issues of concern to themselves. Experiences expressed by young people show that they need to be listened to, to have a voice, to gain new skills, to be a part of a team and to have possibilities to get involved in the community.

The Citizenship Education Longitudinal Study conducted in England found that what goes on in schools, in classrooms, corridors and grounds can have an influence on what students think, know and do in relation to citizenship education and wider citizenship issues. For example, students in all year groups associate citizenship more with rights and responsibilities and 
issues of identity and equality than with formal political processes. The research also found that school is only one of the contexts or "sites" that have an influence on a student's development of citizenship dimensions. The research underlines the potential influence of personal, family and community characteristics on student's development of citizenship dimensions. A clear relationship was seen between home literacy resources and feelings of empowerment, level of trust and engagement (Cleaver, Ireland, Kerr \& Lopes, 2005).

Brooks and Holford (2009) state that a key debate within both academic and policy-related literature on citizenship education focuses on the balance between what can be described as "knowledge transmission" and "active citizenship". Furthermore, some educationalists have strongly favoured prioritising an active approach to citizenship learning, whereby young people are encouraged to take part in a wide range of practical activities. Many educationalists have welcomed the emphasis on performing citizenship rather than just learning about it, others have argued that the focus on active citizenship and an individual's responsibilities to his or her community has served to obscure the importance of rights.

Sandström Kjellin and Stier (2008) even claim that although the term citizenship is increasingly used in school guidelines, educational theory and among teachers and researchers, its meaning still remains vague.

Brooks and Holford (2009) state that the interest of citizenship is a part of a response to the perceived problems of living in an increasingly multicultural and ethnically diverse society by helping to foster social cohesion and a common sense of identity, and allocating duties and obligations to a common community. Citizenship Education has also been driven by a concern that young people lack the political knowledge and skills to act effectively as citizens, they argue. Brooks and Holford (2009) conclude that central to many understandings of citizenship is a collective membership and responsibilities to others, which can be a useful antidote to the excesses of societal individualism.

Schreiner and Sjöberg (2007) state that late-modern societies attempt to develop citizens who are self-directed and self-expressive individuals. Consequently, students in classrooms might expect that their values and voices should be taken into account in one way or another. In connection to this, Smith, Lister, Middleton and Cox (2005) comments are of interest as they point to the fact that young people today are targeted as a group for social policy interventions to develop their citizenship although the young today have adopted values of their self.

Faulks (2006) argues that a concept of multiple citizenships can be used, which seeks to move beyond the traditional association of citizenship. Multiple citizenship is suggested when rights and responsibilities have to reach across a range of political institutions ranging from the local to the global level. He claims that to fulfill the statement that all human beings are equal, a citizenship must be internationalist and multi-layered in its obligations (ibid).

Banks (2001) states that citizenship education must be changed in substantial ways to prepare young people to function in the 21st century. Citizens in the new century need the knowledge, attitudes and skills required to function in a global community. 
Niens and Reilly (2012) argue that global citizenship has been suggested as a means of overcoming the limitations of national citizenship in an increasingly globalised world. Furthermore, global citizenship education will fail to overcome ingrained cultural divisions locally and may perpetuate cultural stereotypes globally unless local and global controversial issues are acknowledged, and issues of identity and interdependence are critically examined at both levels. Many years before Niens and Reilly (2012), with examples from an English perspective, and from the aspect of the new subject of citizenship education from 2002 introduced in England, Davies, Evans and Reid (2005) claimed that citizenship education and global education were not the same. They argued that citizenship education seemed to emphasise either community based involvements or classroom based cognitive reflections, while global education tends towards the sentimental, i.e., issues that are to do with "real life" and a critical approach. However, Davies (2006) states that though one may not be able to accurately monitor the impact of a global citizenship education curriculum, the curriculum in itself and its participants can contribute to a global understanding of how the world works or does not work. Sandström Kjellin and Stier (2008) claim education systems worldwide face enormous challenges, arguing that school as socialisation agents must account equally for local, national and global conditions in their education. Moreover, they must stimulate creativity, openness, and a relativistic outlook of the world among the pupils while promoting national and universal values. "They must foster active, critical, global citizens, who yet must adhere to a specific set of values” (s. 10).

In a European study, Eurydice (2005) emphasised three aspects of citizenship education, namely, political literacy, development of critical thought, and active participation. Political literacy embodies a notion of human rights and political and civic institutions, the development of critical thought in the meaning of acquiring social and moral responsibility, and learning to behave responsibly to others. Active participation is about facilitating and encouraging the pupil’s individual community involvement at different levels.

Arnot and Dillabough (2000) criticism is about gender issues such as patriarchy or violence towards women that are generally played down in citizenship education, but the whole question regarding distinctions between public and private sphere does not receive attention.

Lawy and Biesta (2006) state that for the most part, education for citizenship has been seen as an exercise in civics education rather than as a way of developing and nurturing the social and critical capabilities of young people. The Eurydice (2005) found that primary schools in all European countries focus on the skills required developing respect for other children and adults, and how to act or react, but nothing is said about how pupils at schools should obtain such skills.

Some critical voices (Watts (2006)) have been heard about citizens' education and the citizenship curriculum in England that claim that for many young people studying the new curriculum, incumbent democracy can be learned, but it cannot be lived as critical democracy can. The English national curriculum talks of a global rather than a European dimension in citizenship education.

Biesta, Lawy and Kelly (2009) conclude from a research of the way young people aged 13-21 
learn democratic citizenship through their participation in a range of formal and informal practices. Communities that focus on concerns about young people's citizenship should worry about the actual condition of the young peoples' citizenship rather than improving the curriculum for citizenship teaching. Kennelly and Llewellyn (2011), who have examined the discursive construction of "active citizenship" within civics curriculum in three provinces in Canada, argue critically that one of the fundamental goals of citizenship education - to expand access to citizenship participation for all - has failed.

\section{Method}

In this research, textual analysis is used as a method. Current Swedish national steering documents such as curriculum for compulsory school, the Education Act and syllabus for the subject civics are analyzed. To analyze a text means to review the structure of the text and to scrutinize the content, which is done through content analysis (Alvesson \& Sköldberg, 1994; Mc Kee, 2003; Bruhn-Jensen's, 1989). Qualitative content analysis is used in this research because of the interest in how the text describes certain phenomena, i.e. what standpoints government and national authorities like the National Agency for Education take, and what arguments they present in the steering documents (Kohlbacher, 2006). Furthermore, it is of interest to note what contents of the authorities are prioritized and how the texts mirror values and norms. It is also interesting to examine what the texts say about concepts such as gender equality, internationalization, environmental issues, integration, influence and participation, and how and in which context, these words are used.

The content analyses of the texts proceeded through different stages. First, each document was printed out. The next step was to read through all the material several times and to make notes in relation to the notion of citizenship education. The purpose of the research was kept in mind throughout the process, and the theoretical perspective was used as a screen for the text. I have been observant of special words and statements, which seem to be relevant for the research, particularly how and in what order they occur (Börjesson \& Palmblad, 2007; Philips \& Jörgensen, 2002).

\section{National steering documents for the Swedish school system}

The Swedish national school system is based on democratic foundations and the Education Act stipulates that education in the school system aims at pupils acquiring and developing knowledge and values (Education Act, 2010:800). Education should impart and establish respect for human rights and fundamental democratic values on which the Swedish society is based.

In the Curriculum for compulsory schools, preschools and leisure-time centres (LGR11) and the Curriculum for secondary schools (LGY11) are several values that Swedish schools and leisure-time centres shall represent and impart. These values are: inviolability of human life, individual freedom and privacy, equal value for all people, gender equality, and solidarity with weak and vulnerable. In accordance with ethics, managed by Christian tradition and Western humanism, this can be actualised by fostering a sense of justice, generosity, tolerance and responsibility among individuals. Furthermore, it is stated in both curriculums that those 
activities must be non-denominational (Skolverket, 2011). Each and every person working in the school should also encourage respect for the intrinsic value of each person and the environment we all share. Moreover, the school has a responsibility to counteract traditional gender patterns, and should provide scope for pupils to explore and develop their abilities and interests independently of gender affiliation.

One part of the both curriculums focuses on understanding and compassion for others where it is stated that the school should promote understanding of other people and the ability to empathise so that no one should be subjected to discrimination or other degrading treatment on the grounds of gender, ethnic affiliation, religion or other belief systems, transgender identity or its expression, sexual orientation, age or functional impairment.

The Education Act (2010:800) stipulates that the education provided in each school form and in the leisure-time centre should be equivalent, regardless of where in the country it is provided. However, equivalent education does not meant that the education should be the same everywhere or that the resources of the school are to be allocated equally (Education Act, 2010:800).

In both curriculums, it is stated that it is not sufficient for teaching to only impart knowledge about fundamental democratic values. A school should also apply democratic working forms in practice that can prepare pupils for active participation in the life of society. In the Curriculum for the compulsory schools, preschools and the leisure-time centres (LGR11), the aim is to see that schools, in partnership with the home, should promote all round personal development of pupils into active, creative components and responsible individuals and citizens. In a deeper sense, it means that education and upbringing involve developing and passing on a cultural heritage - values, traditions, language, knowledge - from one generation to the next. Curriculum for secondary schools (LGY11) states that the main task for the secondary school is to impart knowledge and create opportunities for students to acquire and develop skills.

The Curriculum for the compulsory schools, preschools and the leisure-time centres (LGR11) claims that creative activities and games are essential components of active learning and that the school should stimulate pupils' creativity, curiosity and self-confidence.

In both the curriculums, there are four different perspectives identified with the motive that it is important for overall well-balanced perspectives to be established in all types of education. These perspectives are historical, environmental, international and ethical. An historical perspective comes with the expectation that a historical approach will enable the pupils to develop an understanding of the present and prepare them for the future. In case of environmental perspective, there is hope that it will provide young people with opportunities not only to take responsibility for the environment in areas where the young themselves can exercise direct influence but also help to form personal opinions with respect to overarching and global environmental issues. In both the curriculums, it is stated that teaching should illuminate how the functions of society and our ways of living and working can best be adapted to create sustainable development. In the curriculums, the international perspective is also looked upon as important. It is argued that an international perspective can help pupils to 
understand one's own reality in a global context and create international solidarity. It will prepare young people for a society with close contacts across cultural and national borders.

\section{Syllabuses for civic studies at Compulsory- and Upper secondary school}

The subject civics is, by nature, interdisciplinary. It is based on political science, sociology and economics along with other social science and humanities disciplines that are included. The subject also has a historical perspective and with the aid of concepts, theories, models and methods from all these disciplines, complex social issues are understood and explained (Skolverket, 2011).

The subject social studies will be aimed at broadening, deepening and developing the students' knowledge of people's lives, based on various social issues. Political, social and economic ties link people in various communities throughout the world today. The students have the opportunity to develop knowledge of issues affecting power, democracy, equality and human rights, including children and young people's rights under the Convention on the Rights of the Child. Students should also be given the opportunity to develop an understanding of the issues of labour, resources and sustainable development (Skolverket, 2012).

The syllabus for civic studies presented in the Curriculum for the compulsory schools, preschools and leisure-time centres (LGR11) starts with the statement that today people in different parts of the world are facing both opportunities and problems linked to globalisation, intercultural relations and sustainable development. It is argued that knowledge of society gives us tools allowing us to orient ourselves and take responsibility for our actions in a complex world. The aim of teaching civics, as hoped in the syllabus, is that the pupils are given the opportunity to develop an overall view of societal questions and social structures in which the social, economic, environmental, legal, media and political aspects are fundamental. It is argued that teaching should help to develop the pupils' familiarity with human rights, democratic processes and ways of working, and encourage them to reflect over human rights and democratic values, principles, ways of working and the decision-making processes. Moreover, it should also develop abilities to search for information about society from the media, the Internet and other sources and assess its relevance and credibility.

A number of core contents are identified in the syllabus regarding what teaching in civic/social studies should deal with in school years 1-3. These core contents are divided into four parts, living together, living in the neighbourhood, living in the world and exploring reality. The content in the part dealing with living together addresses life issues of importance for pupils such as good and evil, right and wrong friendship, gender roles, gender equality and relationships, and norms and rules in the pupils' living environments. Another core content is the history of the local area and the role of Christianity in the school and in the local area in the past. The part named 'living in the world' addresses questions about migration, environmental issues in relation to pupil's everyday life such as those involving traffic, energy and food. Basic human rights such as equality for all people and the child's rights as laid down in the Convention of the Rights of the Child are also addressed. A fourth core content is pointed out in the syllabus as 'exploring reality', which includes methods of 
searching for information from different sources (LGR11).

Education in civics in school years 4-6 is structured within four identified areas: individuals and communities, information and communication, rights and the judicial system, society's resources and their distribution, and decision-making and political ideas. The core content is presented in each of these areas. The indigenous Sami people and other national minorities in Sweden and their rights are discussed. Human rights, their meaning and importance, including the rights of the child under the Child Convention are addressed. Society's need for legislation, some different laws and their consequences, crime and its consequences on the individual, family and society level are discussed. The public sector, what taxes are, and what municipalities, county councils and the state use tax revenues for are talked about. Political choices and parties in Sweden are discussed along with the Swedish Riksdag (Parliament) and governance. The various tasks performed by them and the political dividing lines in the current political issues of importance for pupils (LGR11) are also debated.

For the compulsory school syllabus in school years 7-9, the same areas of education are identified as those in school years 4-6, some of the topics from school years 4-6 are taught in depth and some other perspectives are added. In the topic named 'individuals and communities', the Swedish welfare structure and its functions such as the health care system are discussed. Questions of youth identity, lifestyles and well-being, and how this is affected by factors such as socio-economic background, gender and sexual orientation are addressed. Immigration to Sweden, earlier and now, and integration and segregation in society are supposed to be discussed as well. Opportunities and risks associated with the Internet and communication via electronic media are problematized in the area titled 'information and communication'. Under the heading 'rights and the judicial system', human rights in different parts of the world and the work of different organisations promoting human rights are discussed. The legal system in Sweden and principles of the rule of law are a part of the syllabus. Democratic freedom and legal rights, as well as obligations for citizens in a democratic society, and ethical and democratic dilemmas linked to democratic rights and obligations are also a part of the syllabus (LGR11). Within the area 'decision-making and political ideas' Sweden's political system within the European Union and the Swedish Constitution are discussed. Different states and forms of government in the world, the purpose of the United Nation and its primary mission are problematized.

In the curriculum called 'degree objectives and upper secondary school subjects to high school in 2011 (LGY11)', are presented the purpose, aims and content of the subject civic. The subject civics taught in Upper secondary school is different from that taught in vocational programme and in the college preparatory programme. The content in the introduction course in civics in the vocational programme is more of a course in citizenship where more of democracy, politics and personal finance are taught than scientific talents. The introductory course in the college preparatory programme embraces the content of social science concepts, methods and models along with the content in the introduction course as a part of the college preparation. As mentioned earlier, the content and credits that students learn in civics in Upper secondary school differ if they go to a vocational programme or a college preparatory programme. The content of the common course in civics taught to all 
college preparatory programmes is divided into several themes such as democracy, human rights, finance, labor market, international law, scientific concepts and methods and information technology.

In the curriculum called 'degree objectives and upper secondary school subjects to high school in 2011 (LGY11)' are claims that education in civics shall treat certain central concepts. These central concepts are very similar to the content in the Curriculum for compulsory schools, preschools and leisure-time centres (LGR11). In brief, they cover the following areas: Democracy and the political system at local, national and European Union levels, and citizens' potential to impact the political system at different levels. It is stated in the curriculum that education shall treat the human beings; who they are, how they relate to the state and the individual, and how one exacts one's individual and collective human rights from laws such as international law of armed conflicts. Furthermore, the contents in the subject civics at the upper secondary school are labor, employment and questions of environment. Questions about personal finance, economics, economic structures and flows in Sweden and internationally are also discussed. Mass media and information technology's role in society are also a part of the syllabus. Finally, social concepts, theories, models and methods in connection with investigations of social issues and social conditions also find place in the syllabus.

The knowledge requirements for the courses in Upper secondary school are rated from A to E. Besides the base courses in civics, a course named international relations is also provided. The syllabus for the course international relations illustrates what students can achieve after the course has been completed. For rating E, it is suggested that the student can give an overview of how various national and international conditions and circumstances are affected by international actors and also give an overview on some theoretical perspectives on international relations. Furthermore, the student can analyze the cause and consequences of international cooperation and conflicts with some certainty. Finally, for the fulfillment of grade $\mathrm{E}$, the requirements are that pupils can, with some certainty, search, view and interpret information from various sources, make appropriate references to sources and make simple reflections on the sources' relevance and credibility. The students can, with some certainty and in a structured way, express their knowledge of social studies in various forms of presentations. Grade D means that the demand of knowledge requirements for grade $\mathrm{E}$ and for most of grade $\mathrm{C}$ is fulfilled.

For grade $\mathrm{C}$, the criteria are that the students can explain in detail how different national and internal conditions and circumstances affect and are affected by international actors. They are also supposed to discuss, in detail, some theoretical perspectives on international relations and their strengths and weaknesses with reference to various sources. Moreover, students are supposed to discuss, in detail, solutions to international conflicts and problems, and make well informed arguments for various positions on the consequences of globalization and its importance.

Grade B means that the demand of knowledge for grade $\mathrm{C}$ and for most of grade $\mathrm{A}$ is fulfilled. Finally, to fulfill the requirements of grade A means that students must explain in greater 
detail how the various national and international conditions and circumstances affect and are affected by international actors. They must also provide nuanced theoretical perspectives on international relations. Students must use some relevant concepts, theories, models and methods in the analysis of causes and consequences of cooperation and conflict for greater impact. Their strengths and weaknesses are supposed to be discussed in greater detail and nuanced with references to various sources such as solutions to international conflicts and problems. Students must be able to make informed and nuanced arguments for various positions on the consequences of globalization and the importance of international collaborations. They must be able to evaluate positions and give detailed reviews. Finally, for the fulfillment of grade A in working with social issues, students are supposed to search for, examine and interpret information from various sources, making appropriate references to relevant sources.

\section{Discussion and conclusion}

In the both curriculums in this research, Curriculum for the compulsory schools, preschools and leisure-time centres (LGR11) and in the Curriculum, degree objectives and upper secondary school subjects to high school in 2011 (LGY11), there is a strong emphasis on the skills or abilities a citizen needs to be assumed a part of the society. The skills that a citizen is expected to have, in addition to knowledge of society, is the ability to actively participate in society. From both the curriculums in this research, it is found that citizenship education in the Swedish school system has a broader sociological and historical meaning to cultivate a sense of justice, generosity, tolerance and responsibility among young people.

In the curriculums is an expectation that pupils in Swedish schools should be given the opportunity to actively take part in the development of their citizenship. From the textual analysis of the documents in this research, it seems like the students have that in theory. In the Swedish school system, it is also assumed that education is equal no matter where it is imparted, and theoretically, all students have equal opportunities to take part in and influence public activities. This research does not give an answer to whether young people actually have those opportunities in practice within the Swedish school system. The syllabus for compulsory school and the one for upper secondary school are very similar in terms of content. The progression can be seen mainly in the way that the scientific work develops and the complexity of the content, and how it is presented in the syllabus for upper secondary school. A social issue can, for example, be illustrated from different perspectives and be connected to any social science theory. For college preparation courses, it is primarily the scientific perspective that carries the added complexity.

Biesta, Lawy and Kelly (2009) argue that it is necessary that citizenship education teaches democratic citizenship through young people's participation in a range of formal and informal practices and communities, and that focus on young people's citizenship should lie in a concern for the actual condition of young people's citizenship. From the curriculums in this research, one can notice that this is a fact in the syllabus from school years 1-3 as it takes its standpoint from themes like living in the neighbourhood and living together, but it is less seen in the syllabuses that includes training in later school years. 
Furthermore, the textual analyses show that the syllabuses for civic studies both at compulsory and upper secondary school show expectations that students will have the opportunities to develop knowledge of issues affecting power, democracy, equality and human rights, including children and young people's rights under the convention on the rights of the child. The syllabuses also express an expectation that students will be given the opportunity to develop an understanding of the issues of resources and sustainable development.

Ross (2007) argues that education for active citizenship must address and encompass both the nature of multiple identities and the extension of civic rights to minorities. A motive is that certain rights have been placed above the nation-state, for example, the Universal Declaration of Human Rights that places a moral obligation on the signatory states to respect greater rights. An analysis of the documents in this research, of both the curriculums and syllabuses, shows that the Swedish authorities have paid attention to this. In civics, a part of the studies includes the indigenous Sami people and the other national minorities in Sweden. The documents mentioning the fact that Sweden is a member of the European Union form a part of Swedish schools' syllabus.

Niens and Reilly (2012) argue that global citizenship has been suggested as a means of overcoming the limitations of national citizenship in an increasingly globalised world. Brooks and Holford (2009) similarly claim that the interest of citizenship is a part of a response to the perceived problems of living in an increasingly multicultural and ethnically diverse society by helping to foster social cohesion and a common sense of identity, as well as duties and obligations to a common community. Sweden as well as other countries in the word are a part of that globalisation, and of increasingly multicultural societies. This is also something that has been taken into account in the governing documents of the Swedish school system. For example, in secondary schools, the content includes 'immigration to Sweden' in a historical perspective, and 'integration and segregation in a society'. In upper secondary schools, the syllabus contains international relations and consequences of globalization. However, one must remember that to express an intention in a steering document is no guarantee that young people really have developed an understanding of how the world works or not works, and that they live and act on the basis of that knowledge. A desire is expressed in both curriculums that students form a personal opinion with respect to overarching and global environmental issues.

Arnot and Dillabough (2000) criticise that gender issues such as patriarchy or violence towards women are generally played down in citizenship education, and the question of distinctions between the public and private sphere does not arise. In national steering documents for the Swedish school system, a number of core contents are identified in the syllabus with respect what teaching in civic/social studies should deal with in school years 1-3. The content in the part named 'living together' addresses life issues of importance for pupils such as gender roles, gender equality and relationships, and norms and rules in pupils living environments. In school year 7-9, questions of youth identity, lifestyles and well-being and how this is affected by such factors as socio-economic background, gender and sexual orientation are addressed. It seems like this claim is fulfilled in some of the national steering 
documents. However, this is less visible in the syllabus for teaching in civics.

Democracy and the political system on local and national level and in the European Union, and citizens' potential to impact the political system on different levels are a part of the both curriculums in this research.

Lawy and Biesta (2006b) state that for the most part, education for citizenship has been seen as an exercise in civics education rather than as a way of developing and nurturing the social and critical capabilities of young people. The critical approach put forward by Lawy and Biesta (2006) seems to be acknowledged in the Swedish national steering documents.

In order that citizens can make their voices heard beyond voting in elections, both curriculums and syllabuses in this study emphasize that the students shall be able to express their knowledge and understanding, both written and verbal, by means of modern information technology. This is suggested to be carried out with the help of blogs, opinion pieces and structured discussions. The critical voice about citizens' education and citizenship curriculum in England from Watts (2006) concluding that incumbent democracy can be learned, but cannot be lived as critical democracy can, does not seem true in case of the Swedish schools national steering documents. Nor does the argument that the content in the subject civic has been formulated considering a small turnout among Swedish young people. On the other hand, the fact that Bennett (2003; 2009) states about civic education reflecting on traditional paradigms of dutiful citizenship oriented to government through parties and voting, is observed as along with a transition to a more self-actualizing style.

Biesta, Lawy and Kelly (2009), and Biesta and Lawy (2006) argue that young people's citizenship learning is not just a cognitive function; rather it is a process that is situated, related and uniquely linked to young people's individual life-trajectories. Furthermore, citizenship education should focus on young people in context and on the social-, economic-, cultural and political context in which they live their lives.

From the analysis of the national steering documents, it is possible to argue that young people in Sweden have the opportunity to both learn about democracy and practice active citizenship. It can also be argued that students have possibilities to be a part of the democratic working forms in practice that can prepare young people for active participation in the society. Values and attitudes are transmitted and transformed in everyday interaction at school and at other meeting places. Teachers at school play a key role in how the students reflect on their pedagogical convictions, on what they see as desirable values and how these attitudes and values are acted out.

To conclude, it seems like the Swedish national steering documents have acknowledged some of the criticism and lack of citizenship education, and added them into the Swedish school system. This research shows and analyses the formulated ambitions on national level, but does not tell how they can be implemented and managed in Swedish compulsory- and upper secondary schools. There are several questions that have to be answered such as what is political rhetoric and what are the educational outcomes of the current pedagogic practice. 


\section{References}

Alvesson, M., \& Sköldberg, K. (1994). Tolkning och reflektion. Vetenskapsfilosofi och kvalitativ metod. [Interpretation and reflection. Philosophy of science and qualitative method]. Lund: Studentlitteratur.

Arnot, M. (2006). Freedom's children: a gender perspective on the education of the learner citizen. Journal of international review of education, 52(1), 68- 87).

Arnot, M. \& Dillabough, H. (Eds) (2000). Challenging democracy: international perspectives on gender, education and citizenship. London: Routledge.

Beauregard, R. \& Bounds, A. (2000). Urban citizenship. In Isin, F., I.. (Eds.) Democracy, citizenship and the global city. London and New York: Routledge, Taylor \& Francis Group.

Beck, U. \& Beck Gernsheim, E. (2002). Individualization. Gateshead: Tyne \& Wear.

Bennett, L., Wells, C., \& Rank, A. (2009). Young citizens and civic learning: two paradigms of citizenship in the digital age. Citizenship Studies. 13(2), 105-120. http://dx.doi.org/10.1080/13621020902731116

Bennett, L. (2003). (www.engagedcitizen.org).Civic Learning in Changing Democracies: Challenges for Citizenship and Civic education. Centre for Communication and Civic Engagement. University of Washington. On line (2008-05-22).

Biesta, G., Lawy, R. \& Kelly, N. (2009). Understanding Young People’s Citizenship Learning in Everyday Life: The Role of Contexts, relationships and Dispositions. Education, Citizenship and Social Justice, 4(1), 5-24. http://dx.doi.org/10.1177/1746197908099374

Biesta, G. \& Lawy, R. (2006). From teaching citizenship to learning democracy: overcoming individualism in research, policy and practice. Cambridge Journal of Education, 36(1), 3-79. http://dx.doi.org/10.1080/03057640500490981

Brooks, R. M. \& Holford, J., A., K. (2009). Citizenship, learning and education: themes and issues. Citizenship studies, 13(2), 85-103. http://dx.doi.org/10.1080/13621020902749027

Bruhn, Jensen, K. (1989). Discourses of Interviewing: Validating Qualitative Research Findings Through Textual Analysis. In Kvale, S. (Eds). Issues of Validity in Qualitative research. Lund: Studentlitteratur.

Börjesson, M. \& Palmblad, E. (red.) (2007). Diskursanalys i praktiken. [Discource analysis in practice]. Helsingborg: Liber.

Cleaver, E., Ireland, E., Kerr, D. \& Lopes, J. (2005). Citizenship Education Longitudinal Study: Second Cross-Sectional Survey 2004. Listen to Young People: Citizenship Education in England. Department for education and skills. Research Report RR626.

Côté, J.E. (1996). Sociological perspectives on identity formation: The culture-Identity link and identity capital. Journal of Adolescence, 19, 417-427. http://dx.doi.org/10.1006/jado.1996.0040 
Davies, L. (2006). Global citizenship: abstraction or framework for action? Educational Review, 58(1), 5-25. http://dx.doi.org/10.1080/00131910500352523

Eurydice. (2005). Citizenship Education at school in Europe. Eurydice. The information network on education in Europe. Cambridge University Press.

Faulks, K. (2006). Rethinking citizenship education in England: Some lessons from contemporary social and political theory. Education, Citizenship and Social Justice. (2006:1:123). (http://www.sagepublications.com). On line (2008-05-21).

Fiehn, J. (2007). Post-16 Citizenship in School Sixth Forms: An Introduction to Effective practice. London: Quality Improvement Agency.

Garratt, D., \& Piper, H. (2010). Heterotopian cosmopolitan citizenship education? Education, Citizenship and Social Justice 2010 5:43. http://dx.doi.org/10.1177/1746197909353568

Giddens, A. (1991). Modernity and self-identity: self and society in the late modern age.Cambridge: Polity press.

Hall, T., Williamson, H., \& Coffey, A. (2000). Young people, Citizenship and the Third Way: A Role for the Youth Service? Journal of Youth Studies, 3(4), 461-472. http://dx.doi.org/10.1080/713684383

Inglehart, R. (1997). Modernization and postmodernization: cultural, economic, and political in 43 societies. Princeton, N.J.: Princeton University Press.

Kennelly, J., \& Llewellyn, K. R. (2011). Educating for active compliance; discursive constructions in citizenship education. Citizenship studies, 15(6-7), 897-914. http://dx.doi.org/10.1080/13621025.2011.600103

Kisby, B., \& Sloam, J. (2012). Citizenship, Democracy and Education in the UK: Towards a Common framework for Citizenship lessons in the Four Home Nations. Parliamentary Affairs, 65, 68-89. http://dx.doi.org/10.1093/pa/gsr047

Lawy, R., \& Biesta, G. (2006). Citizenship-as-practice: The educational implications of an inclusive and relational understanding of citizenship. British Journal of Educational Studies, 54(1), 34-50. http://dx.doi.org/10.1111/j.1467-8527.2006.00335.x

Mc Knee, A. (2003). Textual Analysis: A Beginner London, GBR: Sage Publication.

Niens, U., \& Reilly, J. (2012). Education for global citizenship in a divided society? Young people's views and experiences. Comparative Education, 48(1), 103-118. http://dx.doi.org/10.1080/03050068.2011.637766

Osler, A., \& Starkey, H. (2006). Education for democratic citizenship: a review of research, policy and practice 1995-2005. Research paper in Edcuation, 21(4), 443-466. (www.informaworld.com).On line (2008-05-17). http://dx.doi.org/10.1080/02671520600942438

Petersson, O., Hermansson, J., Micheletti, M., Teorell, J., \& Westholm, A. (1998). 
Demokratirådets rapport 1998. Demokrati och medborgarskap. [The democracy councils report 1998. Democracy and citizenship]. Stockholm: SNS-Förlag.

Philips, L., \& Jörgensen, W. M. (2002). Discourse Analysis as Theory and Method. London: Sage Publications.

Ross, A. (2007). Multiple identities and education for active citizenship. Educational Studies, 44(3), 286-303.

Schreiner, C., \& Sjöberg, S. (2007). Science Education and Young people's identity construction - two mutually incompatible projects? In Corrigan, D., Dillon, J. \& Gunstone, R.(red.) (2007). The re-emergence of values in science education. Rotterdam: Sense Publishers.

Schwartz, S. J, Côté, J-E., \& Arnett, J.J. (2005). Identity and agency in emerging adulthood: Two developmental routes in the individualization process. Youth and Society, 37, 201- 229. http://dx.doi.org/10.1177/0044118X05275965

Sverige. Skolverket.(2012). Ämnet - Samhällskunskap. [Sweden, National Agency for Education. The subject civics]. On line 2012-01-03). (http://www.skolverket.se).

Sverige. Skolverket.(2011). Kommentarmaterial till kursplanen i samhällskunskap. Stockholm: Fritzes. [Sweden, National Agency for Education. Comments on the syllabus in civics].

Sverige. Skolverket. (2011). Läroplan för grundskolan, förskoleklassen och fritidshemmet 2011. Stockholm: Skolverket. [Sweden, National Agency for Education. Curriculum for compulsory school, preschool and leisure-time centre, 2011].

Sverige. (2010). Skollagen (2010:800); med lagen om införande av skollagen (2010:801). Stockholm: Norstedts juridik. [Education Act (2010:800)].

Sverige. Skolverket. (2010). Utveckling pågår: om kvalitetsarbete i fritidshem. Stockholm: Skolverket. [Sweden, National Agency for Education. Development is underway: the quality of work at the youth leisure centre].

Swedish National Agency for Education. Facts and figures 2011. Preschool activities, school-age childcare, schools and adult education in Sweden. Summary of report 363. Stockholm: Skolverket, Swedish National Agency for Education.

Smith, N., Lister, R., Middleton, S. \& Cox, L. (2005). Young People as Real Citizens: Towards an Inclusionary Understanding of Citizenship. Journal of Youth Studies, 8(4), 425-443. http://dx.doi.org/10.1080/13676260500431743

Süllke, F. (2007). Young people and Active European Citizenship. Strengthening Opportunities for Citizenship education on a Local Level: Examples from practice under

Difficult Conditions. Freie Universität Berlin. Berlin Working Paper on European Integration , Nr 2. (http://www.fu-berlin.de/europa). On line (2008-05-23). 


\section{Macrothink}

Journal of Studies in Education ISSN 2162-6952 2013, Vol. 3, No. 2

Vinken, H. (2005). Young people’s Civic Engagement. The Need for New Perspectives. In Helve, H. \& Holm, G. (2005). (Eds.). Contemporary Youth Research. Local Expressions and Global Connections. Hampshire: Ashgate Publishing.

Watts, M. (2006). Citizenship education revisited: policy, participation and problems. Pedagogy, Culture \& society, 14(1), 83-97. http://dx.doi.org/10.1080/14681360500487496 